\title{
ARE PRICES STICKY DOWNWARDS? THE EFFECT OF TRADE LIBERALISATION ON SOUTH AFRICA'S WINE INDUSTRY
}

\begin{abstract}
S. SSEKABIRA NTEGE AND C. HARMSE
THE IDEA THAT InTERnATIONAL TRADE is the engine of economic growth goes back to the times of Adam Smith (Edwards, 1993: 1358). However, its popularity subsided around the 1950s, 60s and 70s in favour of 20 century protectionist' theories, especially in developing countries where Import Substitution Industrialisation (ISI) strategies were implemented.

Persistent, independent academic research during the reign of the protectionist paradigm rejuvenated support for more open and outwardsoriented trade. Gradually, in the 1980s, protectionist theory yielded its hold on economic advisors and politicians (Edwards, 1993:1359). Behind this change of paradigm was the widespread debt crisis in 1982 among ISI followers, and the collapse of communism in central and Eastern Europe. Latin America provides examples of the many countries left injured by protectionist policies. In contrast there was the success story of certain East Asian countries, which had intensively adopted an outward-oriented strategy. This policy thus gained popularity
\end{abstract}


among economists, was preached as indisputable, and was recommended as a panacea that transcended a country's initial level of development in its delivery of gains from trade. De Wet (1995) summarised it thus: 'The theory may not have been designed in the first place for these specific countries - Far East Asia Tigers - but their experience still validates the theories'.

Among the many paradigm converts were organisations such as the World Bank, the International Monetary Fund (IMF) and the United Nations Economic Commission for Latin America (ECLA).

Recent developments reveal a move away from blanket acceptance of the relationship between free trade and gains from trade. We refer here to free trade's supposed attributes such as economic growth, improved resource allocation based on comparative advantage, enhanced efficiency accruing from increased low-cost global competition, employment of a large variety of intermediate goods and capital equipment (thus improving the productivity of other resources), technological development, an increased variety of produced goods, and better prices. What we are moving to is a more qualified situation-specific relationship (Gunnar \& Subramanian, 2000). There are also doubts as to whether the twin outward orientation and trade liberalisation policy package recommendation is a necessity. Roberts (2000:612), Rodrick (1995) and Amsden (1993) have doubted any connection between free trade or outward orientation and infrastructure promotion, suggesting in fact that the reverse may be true.

Schuh (1976:804) viewed the institutional challenges to the USA and its agricultural economists as being sources of sustaining the movement towards freer world trade, operating in a free floating exchange rate environment. The major challenge is therefore the maintaining of confidence in individual countries' positive perception of the accessibility of international trade markets

The East Asian region has been qualified as owing its success to the active role of government in promoting exports while imports have not yet been fully liberalised (Edwards 1993:1360). Further uncertainty prevails on the grounds that market failures 
and imperfect competition are common occurrences in developing countries (Roberts, 2000). One thus wonders whether liberalisation would in fact elicit the required outcomes.

Ocampo et al. (1998) illustrated the argument that trade liberalisation in developing countries embraces modest benefits but a large and regressive income distribution effect, as well as a negative effect on prices and productivity growth. Zhai and Wang (1998) showed that trade liberalisation can bring-'about both economic efficiency and income equality in China. However, the extent of the gain in efficiency depends on which tax instrument the government chooses to balance its budget.

It is amid this cloudy scenario of the benefits of free trade that the South African wine industry is now empirically investigated. One country's exports are another country's imports. However, an emphasis on the outward-oriented policy ignores its import aspect, and possibly exaggerates the benefits from free trade. This paper therefore investigates whether import prices are lowered when tariffs are reduced. The issue of income redistribution is also pursued. The reliability of the policy in achieving its goal, as well as the policy integration at micro-macro level, is also touched upon.

South Africa was selected for this study because in the first place it represents a typical developing economy (DC). There has been, thus far, scanty empirical evidence on the open trade paradigm in such economies. The focus for the literature so far has been on developed economies (Hanson \& Harrison, 1999). South Africa is also uniquely suitable because it shows a recent and gradually increasing degree of openness, initiated with the abolition of apartheid and the end to international isolation in the early 1990s.

The study is carried out on a microeconomic level. This will enable a more focused and detailed analysis of some of the benefits of free trade and policy appropriateness. The imported commodity considered is wine. This choice was based on several grounds. The commodity (wine) is obtained by processing an agricultural product. It is thus similar to the trend exhibited by many developing countries: adding value to their exports. Some knowledge of the relevant 
elasticities would ease policy decisions in this sector and would be of relevance to all economies that add value to their agricultural products. There is also the opportunity to observe aspects of new trade theory, dominated by two-way trade practices. South Africa (a developing country) offers an example of this two-way trade practice, for it makes and exports wine... which it also imports.

The choice of wine was also due to a realisation of the difficulty of disentangling the effect of price reductions due to a lowering of tariffs, from price changes arising from aspects like technological advances. The latter is expected in case of other imported commodities such as computers. Trade in commodities such as wine depends to some extent on consistent quality over time: does the taste 'stand the test of time'? We thus contend that the quality of wine worth importing is important.

Subsequent sections of this paper contain the following: section 2 contains trade liberalisation specifics in South Africa. Empirical evidence regarding import demand functions appears in section 3. Section 4 contains the theoretical base (trade theory) to the study with import demand theories appearing in section 5. The data and estimation technique are presented in section 6 , while the estimation results are documented in section 7. Section 8 contains policy implications and recommendations. Some conclusions are offered in section 9 .

\section{TRADE LIBERALISATION IN SOUTH AFRICA}

Trade liberalisation in South Africa came about as a result of the failure of the import substitution approach of industrialisation (Roberts, 2000:608). An outward-oriented approach was then adopted. This new approach is associated with the gain in efficiency that arises when markets are deregulated. A voyage through the history of trade liberalisation practices and changes in South Africa follows.

During the 1960s and 1970s, South Africa pursued an import 
substitution trade policy. It thus instituted high trade tariffs and extensive physical import controls (Gunnar \& Subramanian, 2000). Before 1983, 79 per cent of imports were subject to direct import controls. A positive list of permitted imports was established. Thereafter, endeavors to dismantle import controls were embarked on and a negative list of prohibited imports was put in place (Gunnar \& Subramanian, 2000).

An import surcharge was introduced in 1985. First, it was set at 10 per cent, but with time 15 per cent and 40 per cent levels were levied on different import categories. This system was replaced by a generalised export incentive scheme (GEIS) in 1990. South Africa also had a highly complex trade regime. The tariff lines exceeded 13000 in 1980. The tariff range was also the widest (Roberts, 2000) Some sectors were highly protected; agriculture with its 74 tariff lines is an example of this.

In the 1990s (in agreement with the GATT, Uruguay Round recommendations) South Africa embarked upon liberalising its trade regime at both multilateral and unilateral trade levels. It was to phase out tariffs over a 5-year period starting in 1995. The venture entailed reduction in tariff lines; replacement of quantitative restrictions imposed on agricultural imports by tariffs; liberalisation of sensitive industries over an 8-year period, and termination of the GEIS by 1997 (Gunnar \& Subramanian, 2000). At the unilateral trade level, the tariff changes effected have gone below the bounds set by the WTO for 2004. To date, virtually all quantitative restrictions have been eliminated (both multilaterally and unilaterally). Tariff lines and bands have also been considerably reduced. South Africa's tariff regime is now much simplified (Gunnar \& Subramanian, 2000).

In the wine industry, specifically, the following measures have been implemented by South Africa to honour its obligations, in terms of the Marrakesh Agreement, to abolish import controls: the Board of Tariffs and Trade (20/11/96) recommended duties based on volume rather than absolute alcohol; these ad valorem duties were implemented in 1998. Bulk rates at lower levels were also proposed - these arrived on the scene with domestic (South African) bottling and packing, thus contributing to further job creation (Board of Tariffs and Trade, Report \#3638,1996). 
The Department of Agriculture and other role-players had to confirm the proposals. Domestic interests thus received first priority. The monitoring of import controls and the in-depth revision of duties were to be executed gradually, taking into consideration the nature and degree of competition from imports. In terms of the Marrakesh Agreement a bounding rate or custom duty not higher than 20 per cent and not to be exceeded by the year 2000, was set. The import controls set by the board in South Africa would not restrict imports significantly. The customs duty base rate that was 122 per cent ad valorem in 1996 was scheduled for reduction to 67 per cent by January 2001. A surcharge in the range 15 - 40 per cent in respect of wine imports was terminated at the end of 1995. The customs figures for the majority of wines after the removal of the surcharge are 25 per cent ad valorem or less. South Africa is also obliged, through commitment to minimum market per cent access, to provide for the importation of certain quantities of wine. This provision enables importation of these quantities at a customs duty of 14.6 per cent ad valorem (Report \#3638).

It is also argued that the liquor industry in South Africa is not a strategic one that requires (additional) protection. Significant protection simply reinforces existing monopolistic interests to the detriment of South African consumers (Report \#3638:23).

With the above proposed changes and opinions implemented, the consumer will enjoy a greater variety of wine, local and imported. The prices are also expected to be lower as a result of competition and improved efficiency. Consumers will also get back a great fraction of what they previously contributed towards the duty.

\section{EMPIRICAL EVIDENCE ON IMPORT DEMAND FUNCTIONS}

1 This source will be referred to as Report \#3638. 
Empirical evidence on the estimation of import demand functions reveals wide occurrences of data bottlenecks. Mah (1999:499) confirms this. Johnson (2001) identified this problem and also identified what plagues international trade research. This feature is not restricted to developing economies, as is shown by Cole's (1995:135) failure to acquire Japanese import prices by origin. Research is thus restricted to the few countries that have consistent data, for all relevant variables, over the required time frame (Khan 1974:679). With the data availability problem now in perspective, evidence about actual estimates follows.

Most empirical research on (national) import demand functions utilises the single-equation model. This may be attributed to the simplicity in specification and estimation of this methodology. This research will not be an exception. The model's methodology is, however, criticised for lacking theoretical basis and its imposition of restrictive assumptions on the estimated coefficients (Cole 1995:133; Lawrence \& Van der Westhuizen, 1990). Attempts to rectify these flaws have included the development of models such as Kohli's system-wide translog model (as in Cole, 1995). The GDP function approach is also commonly applied (Lawrence \& Van der Westhuizen, 1990), on the assumption that exports and imports can be aggregated. Duffy et al. (1990:470) recommend use of the Armington approach to estimate elasticities of import demand (not export demand). There has also been a use of panel data in recent studies.

The actual specification of the import demand single-equationmodels mostly comprises the income and the relative price variables, in the linear but preferably log-linear form, and a randomly and normally distributed error term (Gafar, 1995; Khan, 1974; Field \& Pagoulatos, 1998). Other researchers have incorporated a lagged import demand variable, to cater for the influence of consumption in the previous period on the current period (Sinha, 2001; Mah, 1999; Ceglowski, 1996; Santos-Paulino, 2002). This stock adjustment variable is however likely to be highly correlated with the income variable and so results in severe multicollinearity. This may change the numerical values of parameters, as well as reduce the 
statistical significance (Gafar, 1995).

Other, additional variables shown to be included in estimations of the import demand function are: foreign exchange earnings (Tambi, 1998; Arize \& Walker, 1992; Paully, 2001), and foreign exchange reserves (Mwega, 1993). Arize and Walker (1992) justify inclusion of the exchange rate variable in the ECM as necessary, since it renders the residuals to the estimated equation nonautocorrelated.

Santos-Paulino (2002:961) and Paully (2001) also include a tax variable, independent of the relative prices. The former claims that the real effects of income and price changes (such as depreciation) on import behaviour become more clear when the impact of import control and/or liberalisation policies is included in the analysis. Santos-Paulino thus warns that import demand elasticity estimations that ignore import policy changes should be interpreted with caution. This issue is most crucial when a study is focused on the effects of trade liberalisation. This study will therefore accommodate this caution.

Empirical evidence on estimation of import demand functions shows the need for qualifications. Literature shows that the import demand in developing countries is assumed to be determined by nonmarket forces (Khan, 1974). It thus follows that imported goods tend to be insensitive to price changes. The qualification areas among others include: economy-specific research, commodity definition, prevailing rates of growth on one hand and the general level of economic development on the other, whether the estimations are bilateral or multilateral and the impact of the model form of estimation on the findings. These considerations (and others) provide room for variation between what is textbook-correct and the reality.

Income elasticities are expected to be positive, significant and in excess of unity (Gafar, 1995). Those for relative prices are expected to be negative, significant, and generally high for - "most" developing countries (Khan, 1974). The long-run price and income elasticities are expected to be greater than the short-run ones (Melo and Vogt hypotheses) according to Gafar (1995). Tambi (1997) and Ceglowski (1996) confirm this trend only in case of income 
elasticities.

The Melo and Vogt hypotheses are commonly investigated to establish the relationship between import demand elasticities and economic development: The core condition is that the economy studied be undergoing rapid transition from heavy protection and slow growth to liberalised, rapidly developing growth. It is assumed that the income elasticities of import demand exhibit a direct relationship to the degree of economic development, but that an inverse one exists between price elasticities of import demand and economic development. Despite the similarities with (the initially studied) Venezuela, Boylan (1987) rejected both hypotheses in the case of the Republic of Ireland. Estimations were done using nonstationary data. Mah (1999) failed to reject the income elasticity and development-hypothesised relationship (in the case of Thailand), but only after overcoming earlier methodological mishaps.

With South Africa undergoing rapid liberalisation, away from the sanctioned and growth-trapped economy - conditions similar to those in Venezuela - one should expect greater long-run income and price elasticities for imported wine. However, the growth rate, which in turn affects economic development, has been wavy.

Regarding the expected signs of the variables incorporated in the import demand function, Gumede (2000) quotes Magee as questioning these expectations. The argument goes that a negative and positive sign can be achieved for the relative price and income variables respectively, if researchers overcome their reluctance to report signs that violated the existing economic theory. The perception of an all-encompassing theory is in essence negating attempts to expand existing theory. The unexpected signs may also be due to model mis-specification.

A positive (negative) relationship is expected between the demand for wine and the real effective (dollar/local currency) 
exchange rate. That is, depreciation of a local currency is associated with a decrease in the volume of imports. Recent empirical literature on (exchange rate) pass-through (PT) may otherwise explain the occurrence of a negative relationship. Given competitive markets, PT may be incomplete due to contractual stickiness in prices (Tivig, 1996:632). 'Perverse' effects on the trade balance (meaning negative reaction to the currency depreciation during the pass-through period) may also result when PT is completed. This PT explanation is appropriate for inter-temporal trade analysis, for demand deficient/constrained economies, and when the import variable is expressed in nominal terms.

The impact of exchange rate on the agricultural sector is twofold: direct and indirect. The direct impact manifests itself through export performance and input prices. In the latter, the input effects may be disaggregated into those arising from (i) input components imported in their entirety, (ii) elements imported as being necessary to a local component, and (iii) demand for locally produced items that are equivalent in use to imported ones. Liebenberg et al. (1991:13) showed that the direct effect causes an 11.1 per cent rise in f.o.b. input prices in response to a 10 per cent rand depreciation. Tariff changes then augment this figure.

The indirect impact of exchange rate fluctuations accrues when local producers, with heavy monopoly power, increase their final product price in line with increases in imported input prices (Liebenberg et al, 1991:13).

Liebenberg et al. (1991) have also shown that the effect of exchange rate fluctuation differs across input categories. The possibility of this impact differing for items in a specified category was also hinted at. Thus, differences in elasticities may lie in analyses of the price structures of the different aggregated input groups and the disaggregated specific inputs. The above may hold for consumer goods as well.

As background to the variation in elasticities of different input categories, the following have been quoted: the importance of the input in farm production; the stock volumes of an input at point of use; the degree of competitiveness of the input supply and statutory 
input price controls; input durability; and the availability of locally manufactured inputs.

The benefits to exporters from depreciation of the exchange rate may not be automatic. They may depend on other factors such as the quantitative importance of exports in the marketing of a product, and on the input mix. In a similar way, automatic conclusions concerning imports and tariff reductions ought not to be made or taken for granted. The final situation incorporates both the producer raised consumer-price (in response to imported input price rises) and the direct exchange rate effects on the inputs, that are locally produced substitutes for the imports. The timing of the exchange rate fluctuation has also an impact-on agricultural production.

On the issue of income elasticities of exports and imports, Bairam (1993:73) when re-examining the results of thirty-five countries, showed that though indeed the established elasticities were statistically significant, they differed greatly from country to country. Khan's (1974:689) income elasticities for imports of 15 developing countries ranged between 0.107 and 2.046 (0.024 and 1.943) while those for price elasticities ranged between -0.633 and $-2.731(-0.246$ and -2.293). These figures are for the equilibrium (disequilibria) twostage least square estimations. Economists have thus not reached a consensus regarding the magnitude of import/export related coefficients (Duffy et al, 1990:468). This mandates further research.

Cole's (1995) research work controls for the possibility that the difference in elasticities can be attributed to the fact that there are different countries importing, and that these import sources differ greatly in terms of their levels of development. Cole analysed Japanese import price elasticities for four regions classified as developed. The industrial activities in these countries are very similar and do give rise to intra-industry trade. Cole also showed that elasticities differ for different years covered in the study, much as they are estimated for the same country. He also registered some positive and negative signed price elasticities.

Cole's findings equally revealed variation in the magnitude of 
import price elasticities across regions of origin. Imports from Australia and the EC were shown to be price inelastic, while those from the United States and the newly industrialising countries (NICs) (Brazil, Korea, and Singapore) were elastic. Elasticities were also shown to differ over time for the same import-source country. The assumption of import demand being a mirror image of export demand is not confirmed in Cole's (1995) paper either. Variations in bilateral and multilateral estimation results may explain this finding. Duffy et al. (1990) pointed out that, unlike export elasticities, the import ones ignore the feedback effects of a country's price on other countries' prices. Bairam (1993) similarly showed that (with a few exceptions such as Yugoslavia) income elasticities of exports tend to exceed those of imports.

It should be clear by now that it is difficult to generalise the findings as applied to developed countries, and later on to hypothesise on the magnitude of the import price elasticities. Generalisation also fails since, as Ceglowski (1996:455) shows, a country's import behaviour cannot even be explained through simple extrapolation of historical relationships and special factors such as the importance of import-compositional shifts. This task is aggravated by deviant results from our a priori knowledge, for economies like the United States, which are expected to have finer data, and whose markets are relatively closer to textbook predictions.

Aggregation of imports is postulated to yield low price elasticities for total imports (Gafar, 1995). This is illustrated in studies on Guyana, Jamaica, and Trinidad and Tobago. The estimated price elasticities were $(-0.13,-0.02, \&-0.53)$ and $(-0.71,-0.58, \&-0.57)$ for the aggregate and disaggregated categories respectively. Results by Ceglowski (1996:448) confirm the above, while those by Boylan (1987:304) run contrary. That aside, the variation in elasticities due to Aggregation and disaggregation has not even any consistently proportional basis that could allow accurate prediction of the expected elasticity magnitude (Gafar, 1995). Aggregation is held to exhibit a downward bias on price elasticities but without specifying how low, low is. The results are not merely economy specific, but commodity sensitive. 
Disaggregation of total merchandise into capital goods, intermediate goods, and consumer-good categories confirms that import price and income elasticities are commodity/category sensitive. Tambi (1998) revealed that imports of consumer goods are more sensitive to price and income changes than non-consumer goods. There is a general tendency for buyers of consumer goods to increase demand for the locally produced ones when the price of imports rises. This general view is partially upheld by Ceglowski's (1996:448) price elasticities findings. The income sensitivity of capital goods is however shown to exceed that of consumer goods. Further disaggregation of consumer goods into durable and nondurable categories yields results that differ between these two categories as well as differing from the broader aggregate group. Boylan's (1987:304) results are on the extreme. The total import price elasticities exceed all disaggregated categories:

What is also left unsaid is the extent of elasticity variations if estimates are conducted singly for each commodity in the consumergoods category, and for each country. According to the Armington model (Duffy et al, 1990:468), products are distinguished by kind (rice, cotton, wheat, etc.) and by place of origin. Is such a qualification model specific? One also wonders whether the nature of commodity (such as luxury, necessity and/or whether differentiated and a component of intra-industry trade), and thus the commodity category composition, would not influence the elasticities? Khan (1974:692) expected a considerable improvement in his estimations if special features of the countries, as well as special circumstances during the period of study, were incorporated into the estimations. Lawrence and Van der Westhuizen (1990:325) recommended disaggregation of exports and imports into several components so as to gain more detailed understanding of South Africa's response to trade and policy changes. This research is one of such follow-ups.

It is amidst these uncertainties concerning the benefits of free trade, and different country and commodity sensitive elasticities, 
that the South African wine industry (imports) will be empirically investigated. A model is to be built to pursue this undertaking and thus terminate uncertainties in this area. The theoretical premises of international trade practices precede the model building.

\section{THEORETICAL BASE: TRADE THEORY}

Trade theory may be broadly categorised into the classical trade theory and the 'new' trade theory. The classical theories embraced in the works of Adam Smith and David Ricardo attribute trade practices to local advantages: absolute or comparative. These are plainly to be seen in local variations in factor endowments as we move from one country to another. On the basis of this comparative advantage, countries specialise, export the outcomes and enjoy gains from trade. In return, they enable their trading partners to enjoy similar trade gains when they import what their trading partners produce. All countries, rich or poor, thus benefit when they participate in trade. On this basis, allocative efficiency is improved. Exports are increased, while domestic consumers benefit from greater import quality, volumes and low prices.

The above neo-classical, equilibrium-driven theory has at its roots assumptions such as perfect competition, constant returns to scale, and benefit-maximising behaviour (Strydom 1995:561). An inbuilt automatic mechanism exists to eliminate international and domestic price differentials in pursuit of equilibrium. Free trade thus results in a pareto optimum by virtue of which participating countries benefit through increasing on the extreme real income, associated with comparative advantage-based production. Neoclassical trade analysis is thus the basis of non-interventionist trade policy and bigbang trade liberalisation (Strydom 1995:562).

The above classical trade theory however fails in some aspects to explain modern international trade practices, specifically on the following premises: the abundance of intra-industry two-way trade, but the absence of the reallocation of resources and desirable income distribution effects assumed to arise with free trade (Krugman, 1994). An alternative theory has therefore been sought and crystallised as the 
new trade theory.

New trade theory explains the domination of international trade by two-way (intra-industry) trade among similar countries. The products are differentiated, and each country specialises in one certain variety and pursues economies of scale in that production: hence reduced unit costs. International trade thus enables producers to incur lower average costs. The consumers' welfare is boosted by the variety offered and the low unit costs. The trade benefits are further complemented by a differentiation of intermediate products, also objects of intra-industry trade. This greater variety also positively correlates with an improved productivity that accrues from the intensified division of labour.

\section{IMPORT DEMAND THEORIES}

Having laid down the theoretical premises explaining the broader practices of a country importing a commodity that it also produces, our next is to narrow our focus to the factors that influence the actual quantities of a commodity imported. It is these factors that will capture the micro impact of trade liberalisation on the importation of wine into South Africa. The import demand theories may be thus explained.

The demand for imports depends on the importing country's income and the price of imports. As income increases, consumption in general increases, part of this income being used to acquire foreign goods. Leon Walras (Stiglitz, 2001) qualifies the sources of income to finance such imports as follows: firstly, an open economy allowing a country to acquire imports by exporting or by borrowing. Secondly, a country able to earn interest on its foreign assets (bonds) and use the interest earned to pay for imports. The third option is an international sale of some or other asset.

The quantity of imports that a country can afford thus depends on the relative prices of imports, multiplied by the source of money be it exports, international sales of assets or interest payments from abroad (less interest payments to foreigners). 
The latter is less significant in the case of developing economies, since most frequently the net interest payment is negative, more being paid out than is received (Krueger, 1997).

Keynes identified an autonomous import component independent of the level of national income, and a fraction proportional to the country's national income (Stiglitz, 2001). The new Keynesian school augmented this explanation by incorporating the exchange rate and the relative price variables. The latter has been chosen, as being relevant and enjoying easily available data in South Africa with which to build a wine import demand model. A tariff rate variable is, however, included on the grounds that this is one of the possible tools through which trade liberalisation is implemented, and because changes in it cause changes in import price.

\section{THE DATA AND ESTIMATION TECHNIQUES}

Three data sources used are the South African Revenue Services (SARS), South Africa Wine Industry Information and Systems (SAWIIS) and the South African Reserve Bank (SARB). SARS provides time series data on the quantities and values (f.o.b.) of all wine imports into South Africa between 1988 and 1999, categorised as 22040030 to 22049999.

The data referred to above is also employed to establish a foreign price index for wines. SAWIS provides data on the domestic goodwine price index for wine sold in bulk. This good-wine price index is used as a component of the relative price index, and again as a proxy for the retail prices of imported wine. This proxy is adopted due to absence of time series data on retail prices of wines imported into South Africa. Faced with this very same problem, the Department of Trade and Industry had to restrict its 1986 analysis of the effects of exchange rates on f.o.b. prices of imported inputs (Liebenberg et al. 1991:13). Cole (1995: 135) experienced a similar problem since Japanese import prices by origin were not available. South Africa is thus no exception among developing countries. 
Data on gross domestic expenditure (GDE) and the real effective exchange is drawn from the SARB Quarterly Bulletins. Given the micro nature of the study, it is deemed desirable to emphasise the single import aspect by establishing the income-independent variable as a percentage of the value of imported wines on GDE. The frequency of all data employed is annual. Data is normalised by deflating it (based on 1995 prices) and then converting it into log form for estimation purposes. The Engle-Yoo three-step estimation technique is employed.

\section{THE ESTIMATED RESULTS}

The long-run wine import demand function estimated is:

$$
L W W_{-} I M P=f\left(L R E L_{-} P, L_{-} R E E R L M P R O{ }_{-} Z, L D U T Y \_R\right)
$$

The double log functional form is employed. The dependent variable ( $\left.L W_{-} I M P\right)$ is the log of imported wine volumes. The independent variables include: relative prices of wine ( $\left.L R E L \_P\right)$, real effective exchange rate ( $L R E E K$ ), the propensity to import ( $L M P R O \_Z$ ) and the tariff rate (LDUTY_R), all in log form. Use is made of the real effective exchange rate because of the varied sources from which South Africa imports wine, and because the rand at times depreciates with respect to some currencies, while appreciating in terms of others. Twelve annual observations are included ranging from 1988 to 1999. This is due to availability of data constraints and, secondly, the reduction in tariff rates having occurred only in the latter part of the period covered. Variation in import categorisation provides yet another constraint on the period covered. Inclusion of data with differing characteristics, in the attempt to increase the data points per se, is likely to result in a heteroskedasticity problem (Studenmund, 2001).

No lagged variables are included in the above estimation. This is firstly due to revelations in Liebenberg et al.'s (1991) study of the reaction of prices of different agricultural inputs to exchange rate fluctuations. The responses occurred either 'immediately' (that is, 
within a quarter of a year following the exchange rate fluctuation), or within a lag of up to three quarters of a year. With the use of annual data, lagging of any explanatory variable is thus assumed to be fruitless. Annual data captures both direct effects (likely to occur immediately) and indirect ones caused by inflation, general wage levels, etc. The major factor encountered is, however, the few data points constraint. Lags were considered in the Error Correction Model (ECM) but dropped after proving insignificant.

Table 1. The Augmented Dickey-Fuller tests for non-stationarity, level and first difference, 1988-1999. (All data series in natural logarithmic form.)

\begin{tabular}{|c|c|c|c|c|}
\hline Variable & Model & Lags & $\begin{array}{lll}\tau_{\tau} & \tau_{\mu} & \tau\end{array}$ & $\begin{array}{ll}\phi_{3} & \phi_{1}\end{array}$ \\
\hline \multirow[t]{3}{*}{ LW_IMP } & Trend \& intercept & 0 & -1.766609 & 1.733447 \\
\hline & Intercept & 0 & -0.47125 & 0.222077 \\
\hline & None & 0 & 0.837106 & \\
\hline \multirow[t]{3}{*}{ LR_EER } & Trend \& intercept & 3 & $-12.44162^{* * *}$ & $76.00774^{* * * *}$ \\
\hline & Intercept & 0 & -0.891926 & 0.795532 \\
\hline & None & 0 & -0.34229 & \\
\hline \multirow[t]{3}{*}{ LMPRO_Z } & Trend \& intercept & 0 & -1.830181 & 2.054129 \\
\hline & Intercept & 0 & -0.005743 & $3.30 \mathrm{E}-05$ \\
\hline & None & 0 & 1.937232 & \\
\hline \multirow[t]{3}{*}{ LDUTY_R } & Trend \& intercept & 0 & -1.612086 & 1.823529 \\
\hline & Intercept & 0 & -0.452266 & 0.204545 \\
\hline & None & 0 & -1.017272 & \\
\hline \multirow[t]{3}{*}{ LREL_P } & Trend \& intercept & 0 & -1.90641 & 1.818895 \\
\hline & Intercept & 0 & -0.985599 & 0.971405 \\
\hline & None & 0 & -1.225751 & \\
\hline \multirow[t]{3}{*}{$\Delta \mathrm{LW} \_$IMP } & Trend \& intercept & 1 & $-4.046328^{*}$ & 5.495569 \\
\hline & Intercept & 1 & $-2.927748 *$ & 4.308871 \\
\hline & None & 1 & $-2.254025^{* *}$ & \\
\hline \multirow[t]{3}{*}{$\triangle$ LREL_P } & Trend \& intercept & 0 & -2.45522 & 3.192433 \\
\hline & Intercept & 0 & -2.643667 & $6.988977^{*}$ \\
\hline & None & 0 & $-2.629966^{* * *}$ & \\
\hline \multirow[t]{3}{*}{$\triangle L R \_E E R$} & Trend \& intercept & 0 & $-5.276164^{* 0 k k}$ & $13.98399^{* k \mathrm{k}}$ \\
\hline & Intercept & 0 & $-5.276164^{* * * *}$ & $7.288035^{*}$ \\
\hline & None & 0 & $-2.827647^{\text {*akk }}$ & \\
\hline \multirow[t]{3}{*}{$\triangle$ LMPRO_Z } & Trend \& intercept & 0 & -3.029436 & 4.605610 \\
\hline & Intercept & 0 & $-2.978043^{*}$ & $8.868738^{* *}$ \\
\hline & None & 0 & $-2.349407^{\text {*ak }}$ & \\
\hline \multirow[t]{3}{*}{ ALDUTY_R } & Trend \& intercept & 0 & -3.335381 & 5.617643 \\
\hline & Intercept & 0 & $-3.162276^{*}$ & $9.999992^{* *}$ \\
\hline & None & 0 & $-2.999999^{\text {*akk-k }}$ & \\
\hline \multicolumn{5}{|c|}{ *(**) Significant at a 5 (1) \% level. } \\
\hline \multicolumn{5}{|c|}{$\begin{array}{l}\text { At the } 5(1) \% \text { significance level the Mackinnon critical values are }-3.56(-4.29) \text { for the trend and constant } \\
\text { specification_ }\left(\tau_{\tau}\right) \text { and }-2.96(-3.66) \text { when only a constant is included }\left(\tau_{v}\right) \text {, and }-1.95(-2.64) \text { for the none }\end{array}$} \\
\hline
\end{tabular}


constant are included $\left(\Phi_{3}\right)$ and 5.18 (7.88) when only a constant is included $\left(\Phi_{1}\right)$.

The variables were tested for stationarity, and the following results were obtained.

All variables, dependent and independent (in Table l) are of order 1 , while the residual (Table 2) is integrated of order zero. Given the few data points dealt with in this research — only 12 years of observation - the residual test cannot yield significant results, based on the Mackinnon values. However its stationarity was conformed graphically. Thus the requirement for a cointegrated equation is satisfied.

Table 2. The augmented Dickey-Fuller test for non-stationarity of the long-run equation residual, level, no intercept and no trend, 1988-1999. (Data series in natural logarithmic form.)

\begin{tabular}{llllllll}
\hline Variable & Model & Lags & $\tau_{\tau}$ & $\tau_{\mu}$ & $\tau$ & $\phi_{3}$ & $\phi_{1}$ \\
IMPRES & NONE & 0 & $-3.397879 * * *$ & & \\
\hline
\end{tabular}

Table 3 below provides summary statistics of South Africa's wine import demand function.

Table 3. The long-run equation for wine imported into South Africa

\begin{tabular}{llll}
\hline Variable & Coefficient & Standard Error & T-statistic \\
LREL_P & -1.064591 & 0.092669 & -11.48808 \\
LR_EXCR & -2.111091 & 0.676628 & -3.120019 \\
LMPRO_Z & 0.636010 & 0.115681 & 5.497972 \\
LDUTY_R & 0.318189 & 0.344091 & 0.924724 \\
$(\mathrm{C})$ & 9.638558 & 3.632478 & 2.653439 \\
\hline
\end{tabular}

Dependent variable: Demand for imported wine (LW_IMP)

Note: The standard error and t-statistic cannot be used for statistical inference,

Inclusion of both the exchange rate and the relative price variables was based on the experience in South Africa of imperfect passthrough. The best transparent example is provided in the taxi industry. When the rand appreciates, changes in domestic prices/fares are not forthcoming. In contrast, depreciation of the rand is met with more prompt changes (price/fare increases) in South Africa. These transport costs impact on total production costs. Behind this general practice is the profit motive of goods and services providers. 
To put to rest any possible suspicion of the existence of severe multicollinearity (especially between the two variables, exchange rate and the relative price variables), three tests were carried out: (a) a simple correlation test, (b) a $t$ statistic calculation, and (c) a variation inflation factor test (VIF).

The results were, respectively:

(a) 0.299, (b) $|t|$ of $0.9908<2.365$, the critical value, and (c) the $V I F\left(\hat{\beta}_{s}\right) 1.4296,4.9441,9.0827$, and 3.2581, when LR_EXCR, LREL_P,

LMPRO_Z, and LDUTY_R, were employed as dependant variables respectively. Given that the long-run equation has many independent variables (four), the VIF $>10$ rule of thumb (Gujarati 1992) was adopted when establishing whether severe multicollinearity prevailed.

The results from the three tests conform the absence of severe multicollinearity. Furthermore, the fact that the respective $R^{2} s$ (0.300503, 0.797740, 0.889930, and 0.693071) do not exceed the long run equation $R^{2}(0.995890)$ is another sign of there being no severe multicollinearity. These test results should thus give credence to the variables included in this research as embracing no perturbing multicollinearity.

An ECM for the imported wine demand function is established to be the following (Table 4).

Table 4. The ECM for demand of imported wine

\begin{tabular}{llll}
\hline Variable & Coefficient & Standard Error & T-statistic \\
RES_IMP(-1) & -0.711751 & 0.270590 & -2.630367 \\
D(LREL_P) & -1.010115 & 0.036670 & -27.54598 \\
D(LR_EXCR) & -0.924461 & 0.420901 & -2.196387 \\
D(LMPRO_Z) & 0.823842 & 0.080697 & 10.20910 \\
C & -0.046923 & 0.024439 & -1.919968 \\
\hline
\end{tabular}

$t=\frac{r \sqrt{n-2}}{\sqrt{1-r^{2}}}$ 


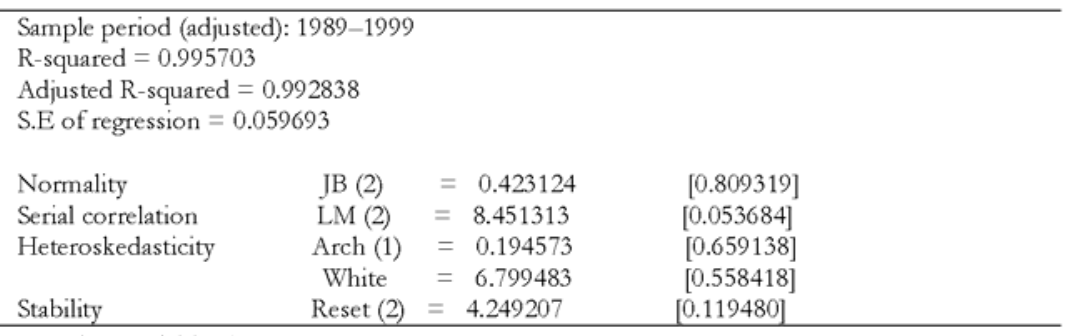

Dependent variable: $\Delta \mathrm{LW}$ IMP

Both the two explanatory variables in the ECM above, relative prices and the propensity to import wine, are statistically significant in the explanation of the dependent variable. This is depicted by the t-statistic values being greater than 1.96 in absolute terms for all the explanatory variables. The $\mathrm{R}^{2}$ (adjusted R-squared) of 99.5 (99.2) per cent - an index of how well the estimator 'fits' the sample data — also signifies an overall good fit. The LM test indicates no existence of serial correlation (5.3 $>5$ per cent), likely as such correlation is when dealing with time series data. Other components of the diagnostic tests are significant at the 5 per cent level, hence suggesting an absence of statistical problems such as heteroskedasticity. The standard error of regression (at 5.9 per cent) does merit the quality of this ECM for it signifies a small margin between the ECM and the actual import value.

The short-run and long-run coefficients of relative prices (in Tables 3 and 4 respectively) are correctly signed (-), and statistically significant (short-run). Both elasticities are slightly above unity. The long-run elasticity is also larger (in absolute terms) than the short-run one, as expected. The price elasticity of import demand is expected to rise as the country's ability to substitute domestic production for imports increases over time. The desire for variety would sustain intra-industry trade, but local production would increase its share of the domestic market.

The long-run price elasticity compares well with those estimated by Tambi (1998) and Ceglowski (1996), -1.186 and -1.29 for Cameroon and Japan respectively, both estimating the disaggregated consumer goods' elasticities (non-durable for the latter). The low price elasticity may be justified on grounds that the aggregated wine commodity considered in 
this study is a non -homogeneous good. Secondly, the magnitude of price elasticities has been empirically recorded to differ depending on the nature of importer and his responsiveness to price changes. Duffy, et al (1990:473) showed that (the trade-weighted) elasticities declined from -4 to -1.6 for price responsive, centrally planned importers, and from 1.5 to -1.0 for non price responsive, centrally planned importers. Importers who absorb tariff reductions give rise to non-responsive behaviour. The fact that they are few, and act in their common interest, resembles centrally planned importers. The short-run results (-0.322 and -0.355 respectively), however, are- smaller in magnitude than this paper's findings, but of the same desirable sign.

The income variable has the hypothesised positive sign in both the short run and the long run. The long-run value still compares well with those yielded in Tambi and Ceglowski's works (0.668 and 0.79, respectively). However, the magnitude of the long-run income elasticity does not exceed the short-run one. The opposite would have signified increased openness with time. The wavy nature of the rate of economic growth, which is assumed to be stable but was not, may account for this deviant result. As with price elasticity, the magnitude of the long-run income elasticity noticeably exceed the figures established by Tambi (1998) and Ceglowski (1996):0.399 and 0.218, respectively.

The long-run results with respect to the relative prices variable means that an increase in relative prices - with respect to wine - of 1 per cent means a reduction in the importation of wines of 1.06 per cent. Again, when income (spent on imported wine) increases by 10 per cent, the volume of imported wine will increase by 6 per cent.

The exchange rate elasticities are negatively signed, contrary to $a$ priori knowledge but are statistically significant. Tambi recorded such a negative sign, in the short run, but the variable was also not significant.

The long-run equation results signify that a depreciation of 1 per cent would give rise to an increase in imported wine of 2.1 per 
cent. The negative sign before the real effective exchange rate thus implies that depreciation of the rand against a basket of major tradepartner currencies leads to increased expenditure on imported wine.

The increase in demand for imported wine at times when the rand depreciates is due to supply constraints (and the associated cobweb theorem). Lawrence and Van der Westhuizen (1990:325) showed that in the South African economy, production responsiveness is generally inelastic (more so, in the agriculture sector). It is this production inelasticity that in part favours the stickiness of prices downwards. Local producers take advantage of the increased foreign market caused by the depreciation of the rand, thus bringing about a shortage of locally produced wines. Consumers thus resort to the imported article.

The fall in value of the rand also has a cost impact on input prices (Van Schalkwyk, 1995:17). This is likely to result in an increase in consumption of imported wines. With a rise in input prices, and thus in the price of the final commodity, locally, the relative import price disadvantage dwindles. According to Van Schalkwyk, if domestic producer prices of agricultural commodities remain constant when the rand weakens, then the competitive position of South Africa's producers will be eroded. The producers thus insist on raising the price by at least the increase in production cost. The final scenario depends on whether the import-discouraging effect of the depreciation of the rand outweighs the cost-push impact on the local product prices. This also depends on whether the local producers actually increase their prices by the bare minimum required to reinstate them in their competitive position.

Liebenberg et al. (1991:15) talked of the rise in price as being up to that considered psychologically favorable for the business conducted. Thus for a profit-pursuing undertaking, one would expect the price rise to exceed the minimal requirement, more so for a powerful farm bloc (such as the KWV). Businesses in industries with little competition are very willing to manipulate prices in their favour in response to tariffs or exogenous shocks to the exchange rate. The more the degree of ownership concentration - likely in a country newly admitted to international trade - the less inclined firms will 
be to reduce prices when import costs decline (Liebenberg et al, 1991:17).

The tariff variable is revealed to be positively related to the demand for imported wine. This result is contrary to normal expectation but captures the aspect of prices being sticky downwards. The magnitude of the coefficient - in absolute terms - compares well with the findings by Santos-Paulino (2002). This issue of price stickiness downwards may be confirmed by analysing the regression results jointly with the separate statistical test on the correlation between import prices (f.o.b. plus the tariff rate) and the good-wine (local product) retail prices Since the wine that is imported is good quality wine, the local good-wine product provides a close substitute for the import and is thus used as its proxy. A reduction in the price for imported wine should thus elicit a similar trend in the price of the local product. The correlation result is -0.590835 .

The above figure manifests a negative correlation between imported wine prices and the good wine locally produced. Thus a decrease in the price of imported wines does not elicit the anticipated reduction in the prices of locally produced good-wine, its close substitute.

Combining the findings, one may conclude that when the tariff on imported wine is reduced, the volume of imported wine also falls. This positive relationship accrues from the inverse correlation established above. A reduction in imported wine tariffs does not result in a fall in price of the imported commodity as shown by the price of its close substitute. Instead, a price increase follows. This points to the stickiness of imported wine prices. With the rise in price of imported wine that occurs despite the reduction in the tariff rate, the volumes imported also fall: thus the positive result shown in the regression.

The importers thus absorb the tariff reduction on the imported wine prices. This renders the tariff variable an insignificant determinant of demand for imported wine. The anticipated benefits to the consumers due to the opening up of the economy are thus in vain. Instead, greater income inequality results. The situation is aggravated by the fact that the revenue previously collected by the 
government (and spent in the common interest) is not passed on to the consumer as intended, but to the (minority) importers.

The result with respect to the tariff rate variable and the associated downward stickiness in imported wine prices are complemented by that arising from the real effective exchange rate. In both cases, the general pattern is that more is bought when the price of the imported wine rises, irrespective of the cause of price rise. The (absolute) magnitude of the exchange rate variable is however larger, since its impact penetrates through various channels, compared with the wine-specific import tariff, characterised as it is by a greater absorption loophole. The removal of tariffs eliminates the distortion of consumption choices, but this distortion is sustained through the wine importer's act of absorbing the tariff reduction in pursuit of greater profits. The removal of tariffs also has another undesirable effect - that of worsening the terms of trade.

Determination of a price (and thus consumption of a commodity) incorporates many factors. Exchange rates and tariffs are only two of them. Each of these factors has little and differing explanatory power when influences upon the final price are analysed. The extent to which economic agents can manipulate these factors also differs. The more narrowly encompassing the factor (in terms of its immediate effect on economic activities), the greater the degree to which specific agents may manipulate it in their favour. For example, a tariff on wine is highly specific to an economic group (importers). Cooperation by such a small number of market participants is easier and beneficial to all of them. Tariffs are thus easier to manipulate by the importers than would be the widely encompassing factor (the exchange rate) which offers more percolation points. This may explain why the exchange rate variable is a more significant determinant of the consumption of imports. 
The degree of manipulation also depends on the extent of market perfection in the country. An aggressive business such as the South African taxi industry (with greatly skewed 'rights' between passengers and operators) may also easily manipulate a price-influencing factor (depreciation of a currency) in their favour.

A caveat has, however, to be made about the above results. Much as the utilised Ordinary Least Square estimation technique is superconsistent under conditions of cointegration, it tends to bias given the few data points. This may be the case given the small number (12) of observations and the low degrees of freedom involved in this research. The narrow study period is due to the data related constraint. There is a general absence of relevant data. Lawrence and Van der Westhuizen (1990) experienced a similar problem in their study on trade elasticities for South Africa, compelling them to execute a 14year time-series study. The problem is compounded by changes in commodity classification by SARS, over time (thus setting limits to how far back the study can be stretched), and the fact that trade liberalisation and tariff reduction only appeared in South Africa in recent years, that is, after the official ending of apartheid and the consequential termination of trade sanctions. As mentioned earlier, "inclusion of data with differing characteristics, in the attempt to increase the data points per se, is likely to result in a heteroskedasticity problem" (Studenmund, 2001).

However, there is strong conviction that the issue of analysing the trade liberalisation policy implications, at micro level and in previously untested environments, is of such tremendous economic and social importance that it ought to be carried out without waiting for thirty years - the conventional duration considered to yield reliable/representative estimates - to elapse. This convention is, however, also statistically challenged under a methodology such as bootstrapping.

Funke and Ruhwedel (2001:241), having used eight annual 
observations, recommended that further research should be carried out when additional data becomes available. We similarly recommend further studies using panel data (if that type of data is available), to augment the few data points and the findings of this paper.

\section{POLICY IMPLICATIONS AND RECOMMENDATIONS}

The findings of this paper do not confirm the desired part-to-whole policy integration. It instead confirms that macro-economic equilibrium is a neutral rather than optimal concept, the latter being the target of macro-economic equilibrium. The government has thus to decide whether its interest is the attainment of better income distribution at the micro or the macro level. To not consider the micro effects of trade liberalisation is to worsen the poverty levels that trade liberalisation is already alleged to have created (UNCTAD report, 1997).

Opening up has been assumed to automatically embrace increased income redistribution, ignoring the complex linkages and the range of possible outcomes. What results, depends largely on the nature of the import market and, precisely, on the response of the importers. The importers' response is made possible as a result of their monopoly power. Rampant market failure boosts this monopoly power.

The revealed stickiness of wine prices downwards does not confirm the positive relationship assumed between opening up and improved income redistribution. Lower prices are not achieved, partly due to importers exploiting information inefficiencies, and also due to the depreciation of the rand. The former explanation is the principal reason behind the stickiness of prices downwards.

With government revenue forgone, tariff reduction appears antagonistic to the aim of a broader tax system: attaining a more equitable income distribution. A small group in society that is directly engaged in importing activities absorbs all resultant

Panel data were used in their research 
benefits.

We can thus conclude that opening up, in the instance of South Africa's wine industry, has proved inconsistent with what was the target: a more equitable distribution of income. This therefore goes against the Reconstruction and Development Programme statement that: "Our growth path must ensure more equitable distribution of income" (Asghar, 1996:4). It follows that if opening up the economy means transferring more money from the consumers (majority) to the importers (minority), thus amplifying the distribution problem, then opening up has no grounds for justification. Consumers might well have been better off with the tariffs still in place, if the government had allocated the tariff revenue in the public's interest.

Opening up of the economy (without fully liberalising the local market) must, therefore, be given a more critical evaluation. The local scenario has to be considered, otherwise the imported policies superimposed on the South Africa economy, irrespective of the differences in setting, are likely to give rise to undesirable results. Strydom (1995:567) summarised it thus; "In opening up an economy one should not abide by fixed rules or theoretical frameworks, which cannot command empirical support". The great strength and ultimate weakness of the trade liberalisation policy lies in the supposition that it is of universal application. In South Africa the apartheid era embraced much inequality. Therefore, liberalisation without market perfection can easily sustain the grave income distribution disparity.

As a prerequisite to opening up an economy, an institutional infrastructure that is compatible with a market economy has to be established. This would ensure, among other things, easy access of trade information, thus fostering competition. Secondly, given that trade liberalisation is executed together with other economic strategies, a more gradual opening up process would yield more desirable results. This would allow new institutions to mature, as well as leave a nation with some safety-net measures to address undesirable outcomes. There is also a great-need to keep policy implementers' doors open to criticism and advice. 
The core of this evaluation is the availability of data, or the accessibility of the available data. In the absence of data, one would recommend that South Africa (and other developing countries) immediately embark on the establishment of databases that will enable appropriate analysis of policy outcomes. This data issue is crucial in the case of primary production or, more specifically, agriculture. The trend in export performance of most developing countries is towards adding value to primary or agricultural products. Data is, therefore, needed to solve production problems and enable efficient policy decisions to be made.

The promotion of exportable goods and services, and the intended improvement in developing countries' welfare may not be achieved if the undesirable trend in relative prices and real effective exchange rates persists. These two variables are among the significant determinants of the short-term fluctuations in wine imports and indeed in imports generally.

The improved domestic terms of trade, theoretically assumed when a tariff is in place, are eroded by trade liberalisation. The resultant relative price prejudices South Africa's import exercise (as well as that of other developing nations). This is due to the weakening in (non-oil) commodity prices, thus working against developing countries, as revealed by the UNCTAD report (1997). This predicts a bleak scenario for developing nations pursuing trade liberalisation: the negative price trend will show itself by setting back attempts at growth, since fewer imports will be affordable. Ocampo et al. (1998) also reported similar negative price effects.

Developing countries are destined to continue importing products, especially industrial ones. However, their power to import, boosted by increased earnings from exports, is likely to be watered down by the perpetual currency depreciation common in developing countries (and by the undesirable relative price trends explained in the paragraph above). South Africa's exchange rate experiences in the late 1990s and early 2000s clearly illustrate this. Currency depreciation increases the price of foreign currency, making foreign goods more expensive. This results in imported inflation, which in turn impacts 
negatively on the inflation-targeting process. The money available for expenditure on imports is in turn reduced. The benefits that would accrue from currency depreciation are rendered minimal by the limited access to developed markets. The overall outcome is an unfavourable balance of payments.

The commodity studied here has close substitutes in the form of the local wine produce. Despite this close parallel, a reduction in tariffs does not result in more imports since wine prices are sticky downwards. The commodity also entails no aspect of change in price due to quality change, or inclusion of new physical components. The possibility of price rises being attributed to drought is minimised by use of time series data and the processed nature of the product. Based on these grounds, the situation is likely to be bleaker for South Africa (and other developing countries) when it comes to commodities such as industrials. These often have no close, locally produced substitutes, and there is still room to manipulate price increases in the name of "improvement" to items or their components.

There is little doubt that trade liberalisation has been effected to a desirable extent by South Africa (and possibly many other developing countries). This is true for South Africa's wine imports specifically, and indeed for imports in general. What remains unsolved is the time span that is deemed desirable for the policy prescription to yield the results desired at macroeconomic level, as well as for those effects to percolate as wished for down to microeconomic areas of activity. Empirical evidence shows that time has an important impact on policy effects, since elasticities change with time even for the same country (Cole, 1995). The outcomes so far, as shown above, are disappointing. The issue of time becomes even more crucial given that trade liberalisation is not executed as a single intervention in a vacuum =jut simultaneously with other policy measures, and remains susceptible to exogenous shocks. 


\section{CONCLUSION}

The hypotheses of this study have been modified by the findings. A fall in relative prices results in more wine being imported. Depreciation of the rand results in more wine being imported. Likewise, an increase in national income (GDE) manifests itself in more volumes of wine being imported. This illustrates the potency of intra-industry trade. Reduction in tariff rates is not accompanied by a lowering of prices of imported wine. It promotes skewed income distribution in favour of certain traders (importers) while going against the interests of consumers. Prices are sticky downwards.

The findings of this paper thus warn against the blanket acceptance of opening up an economy. The assumed benefits (lower prices and better income distribution) are not automatically achieved amid the agitation of today's imperfect markets and market failure. Against expectations, prices of imported wine are seen to be sticky downwards. Supply constraints also fuel an increasing demand for imports at a time when local producers are taking advantage of increased demand in foreign markets arising from the depreciation of the rand.

Data should be collected to analyse the different policy effects at micro level and thus determine the policy's suitability — both locally, and in its necessary integration with the country's broader macroeconomic goals.

The trends in relative prices and a depreciating currency have a negative effect on the ability of South Africa (and possibly of other developing countries) to import. Developing countries are destined to continue importing substantially in the foreseeable future. However, any depreciation of a local currency leads to imports becoming more expensive and so counteracts the improvement in export performance, thus undermining the results of the outward-oriented policy. The trend of weakening (non-oil) commodity prices still further worsens the outcomes of opening up the South African economy to world trade. 


\section{REFERENCES}

AMSDEN, A. (1993). Trade Policy and Economic Performance in South Korea. In: Ago sin, M. \&

Tussie, D. Eds. Trade and Growth: New Dilemmas in Trade Policy. New York: St Martin's Press.

ARIZE, A.C. (1996). Comtegration Test of a Long-run Relation between the Trade Balance and the Terms of Trade in Sixteen Countries. North .American Journal of Economics and Finance, 7(2): 203-216.

ARIZE, A.C. \& WALKER, J. (1992). A Re-examination of Japan's Aggregate Import Demand Function: An Application of the Engle and Granger Two-Step Procedure. International Economic Journal, 6(2): 41-55.

ASGHAR, A. (1996). From the RDP to GEAR: The Gradual Embracing of Neo-Liberalisation in Economic Policy. NIEP Occasional Paper Series, August, 3.

BAIRAM, E.I. (1993). Income Elasticities of Exports and Imports: a Re-examination of the Empirical Evidence. Applied Economics, 25: 71-74.

BOARD OF TARIFFS AND TRADE, Report No. 3638. ((1996) Revision of the Tariff Dispensation Regarding Beverages, Spirits and Vinegar with Recommendation.

BOYLAN, T.A (1987) Elasticities of Import demand and Economic Development: The Irish Experience. Journal of Development Economics, 26: 301-309.

CEGLOWSKI, J. (1996). The Recent Behaviour of Japanese Imports: A Disaggregated Analysis. Japan and the World Economy, 8: 443-457.

COLE, I.M. (1995). Japanese Import Price Elasticities by Region of Origin: 1968-1988. Japan and the Ts World Economy, 7: 131-138.

DE WET, G.L. (1995). The Prognosis for Growth and Development in South Africa. The South African Journal of Economics., 63(4): 473-488.

Duffy, A.P., WOHLGENANT, M.K. \& RICHARDSON, J.W. (1990). The Elasticity of Export Demand for U.S. Cotton. Journal of the Alabama Agricultural Experiment Station. May, Paper no. T-8992136P: 468-474.

EDWARDS, S. (1993). Openness, Trade Liberalisation, and Growth in Developing Countries. Journal of Economic Literature, 31: 1358-1393.

(2000). Understanding the Effects of Trade Policy Reform: The Case of South Africa. South African Journal of Economics, 68(4): 607-638.

FIELD, M.K. \& PAGOULATOS, E. (1998) Foreign Trade Elasticities and Import Discipline. Applied Economics, January, 30(1): 105 (7).

FUNKE, M. \& RUHWEDEL, R. (2001). Product Variety and Economic Growth: Empirical Evidence for the OECD Countries. IMF Staff papers, 48(2): 225-242.

GAFAR, J. (1995). Some Estimates of the Price and Income Elasticities of Import Demand for Caribbean Countries. Applied Economics, 27: 1045-1048.

GUMEDE, V. (2000). Import Demand Elasticities for South Africa: A Comtegration Analysis. Journal for Studies in Economics and Econometrics, 24(1): 21-37.

GUNNAR, J. \& SUBRAMANIAN, A. (2000). Dynamic Gams from Trade: Evidence from South Africa. IMF Working Papers, March, WP/00/45

HANSON, G.H. \& HARRISON, A. (1999). Trade Liberalisation and Wage Inequality in Mexico. Industrial and Eabour Relations Review, 52(2): 271.

JOHNSON, P.R. (2001). The Elasticity of Foreign Demand for U.S. Agricultural products. 2001, The Journal Series of the North Carolina Agricultural Experiment Station, Raleigh. Paper no. 5331.

KHAN, M.S. (1974). Import and Export Demand in Developing Countries. International Monetary Fund Staff Papers, 21: 678-693.

KRUEGER, A.O. (1997). Trade Policy and Economic Development: How We Learn. American Economic Review, 87: 1-21.

KRUGMAN, R.P. (1989). Differences in Income Elasticities and Trends in Real Exchange Rate. European Economic Review, 33(5): 1031-1046. (1994). Rethinking International Trade. London: The MIT Press Cambridge.

LAWRENCE, D. \& VAN DER WESTHUIZEN, G. (1990). Trade Elasticities for South Africa. 
The South African Journal of Economics, 58(3): 318-327.

LlEBENBERG, G.F., VIVIER, F.L. \& GROENEWALD, J.A. (1991). Exchange Rate Depreciation and Costs of Agricultural Input in South Africa. Agrekon, 30(1): 13-17.

MAH,J.S. (1999). Import Demand Liberalisation and Economic Development. Journal of "Policy Modeling 21(4): 497-503.

MWEGA, F.M. (1993). Import Demand Elasticities and Stability during Trade Liberalisation: A Case Study of Kenya. Journal of African Economics, 2(3): 381-416.

NEUHAUS, P. (2000). Dynamic Gams from Trade: Evidence from South Africa. IMF Working Paper, March.

OCAMPO, J., ANTONIO, T. \& LANCE, K ---- I). Trade Liberalisation in Developing Economies: Modest Benefits but I Jms with Productivity. Economic Journal, September, 108(450): 1523(24).

PAULLY, P. (2001,). Prototype model: External sector. Lecture at the UN /AFRICA Modelling Project Workshop 3 (unpublished)

ROBERTS, S. (2000). Understanding the Effects of Trade Policy Reform: The Case of South Africa. The South African Journal of Economics, 68(4): 607-638.

RODRICK, D. (1988). Imperfect Competition, Scale Economies and Trade Policy in Developing Countries. Trade Policy Issues and Empirical Analysis. Chicago: University of Chicago Press. (1995). The Rush to Free Trade in the Developing World: Why so late? Why now? Will it last? In: Haggard, S. \& Webb S. B. Eds. Votingfor Reform. New York: Oxford Univ Press.

SANTOS-PAULINO, A.U. (2002). The Effects of Trade Eiberalisation on Imports in Selected Developing Countries, www.elsavier.com/locate/worlddev

SCHUH, G.E. (1976). The New Macroeconomics of Agriculture. American Journal of Agricultural Economics, 58(1): 802-811.

SINHA, D. (2001). A Note on Trade Elasticities in Asian Countries. The International Trade Journal, Summer, XV(2): 221-237.

SMETS, F. \& WOUTERS, R (2002). Openness, Imperfect Exchange Rate Pass-through and Monetary Policy. European Central Bank Working Papers Series, March, 128.

STIGLITZJ. (2001). What I learned from the World Economic Crisis. The Insider.

STRYDOM, P.D,F. (1995). International Trade and Economic Growth. The Openmg up of the South African Economy. The South African Journal of Economics, 63(4): 556-569.

5TUDENMUND, A.H. (2001). Using Econometrics: a Practical Guide. 4th Edition. Addison Wesley Longman, Inc, New York.

TAMBI, N.E. (1998). Trade Liberalisation Effect on Commodity Imports in Cameroon. Journal of Economic Studies, 25(3): 193-202.

TIVIG, T. (1996). Exchange Rate Pass-through in Two-period Duopoly. International Journal of Industrial Organisation, 14: 631-645.

UNCTAD (United Nations Conference on Trade and Development, 1997). Trade and Development ILeport. New York: United Nations.

VAN SCHALKWYK, H. (1995). How the Exchange Rate Affects Farmers' Input Costs. Farmer's Weekly, 11 August:17-18.

ZHAI, F. \& WANG, Z. (1998). Tariff Reduction, Tax Replacement and the Implications for Income Distribution in China. Journal of Comparative Economics, 26: 358-387. 